\title{
Verification of the Health Care Region in Fukuoka Prefecture
}

\author{
Hiroshi EGAwA \\ Department of Hospital and Medical Administration, School of Medicine, University of \\ Occupational and Environmental Health, Japan. Kitakyushu 807, Japan
}

Abstract: Because the change in the location of industries, if comprehensive health care is to be promoted, there is need to derive a methodology for finding the life cycle patterns of the residents and to set up health care regions from these results. Formally, health care had evolved within the prefecture or the Health Center administrative districts with each spectrum of health promotion, "disease prevention" and "diagnosis, treatment and rehabilitation" using fragmented and unrelated methods. However, there is need to designate the region for health care planning aside from the present units for administrative purposes. With this object in mind, Fukuoka Prefecture, which has experienced a dramatic change in industrial structure, was selected as an example. Regions were designated centering around the analysis of "socio-economic aspects" and "demographic characteristics". From the viewpoint of the relationship with the life style, the geographical extent of the activity of the residents was studied through the commuting areas. Based on this activity range and the geographical distribution of the industrial locations, a reasonable "Region for health care" was designated. The first quantitative approach to verify the results was made by using the weighted pair-group method and principal component analysis. And from the vantage of the Fuzzy Sets-theory, a multivariate technique centering around clustering analysis was next utilized to analyse. Multivariate quantitative analysis confirmed this result, and identical regions were derived at the $16 \%$ level, on the single linkage method of the clustering. Thus, from the analysis of the living area of the residents the health care planning regions of Fukuoka Prefecture were identical whether using the qualitative approach or the quantitative approach.

Key words: regional health care plan, health service area, health care region.

(Received 15 February 1984)

\section{Introduction}

Bound to life and activity of men, there is the economical mechanism centering on industry. The "Social life" of the people should be considered as the central theme and in conjunction with the economical development of the region. The developmental process is said to change from a dependent to an independent type and to progress to a comprehensive social policy (Shomura, 1979). It follows that an economic plan develops into a socio-economic plan and regional development is made centering on the allocation and distribution of economic resources.

In the regional development in Japan since the war, there has been a need for harmony between economy and society and compatibility with the high economic 
growth. However, in actual fact, the development has been limited to the economic field and there has been little or no adjustment between both fields. With economic development, there has been a pressure for each region to conform to the high economic growth society and each central ministry has developed independently a regional administrative planning design. However, these plans lack the comprehensive health care aspect of social development and are mostly limited to developing the environment facilities. This economic development has led to a greater unbalance in income and region resulting in the impeding of economic development, thus forming a vicious circle.

In the wide and complex interrelation of social development, health care is one of the important issues. In spite of this fact, the various establishments have constructed health care facilities in the region with no relation to each other. (Egawa et al., 1981b; 1982). The quantitative and quality change in urbanization and industrialization has caused a change in the disease structure. Therefore, health care providers have to devise on a regional basis an effective method for providing comprehensive health care. Formally, the regional concept was based on the prefectural or the health center administrative district. In contrast, there has been a proposal based on scientific evidence that the health planning region should be based on the everyday living area of the residents (Kurata, 1968; 1969). This regional unit is unique for each case and is not necessarily the same as the administrative unit. It should not be thus uniformally drawn. As each region has its unique physical, chemical, biological, social and psychological environmental characteristics, the fundamental idea should be based on the concept of regionalization and "the community for health care" should be individually planned within the prefecture.

The change in the industrial structure of the region has greatly influenced the daily living conditions of the people. (Tahara \& Suzuki, 1977). Therefore, the systematization of health care provision has to be planned based on each living area of the people (Kurata, 1979). In this aspect, Fukuoka Prefecture has been dependent especially on heavy chemical industries. The post-war change in energy policy and the rationalization of steel industries have led to a complete reversal of the former regional development policies and in turn to a new redevelopment plan (Egawa et al., 1980).

The needed factors for a health care plan for Fukuoka Prefecture in our opinion are research into the relationship between industry and disease, the health problems associated with the eclipse of old industries and the rise of new ones. The fundamental analysis for providing the best health care provision concerning content and range should be made. In this paper, our analysis verifies both the relationship between the administrative district and the daily living area of the residents and the results of the designing of the health planning district based on quantitative sociological methodology.

\section{The Extent of Everyday Life}

First, an analysis was made of the day/night resident population ratio in order to find 
out the extent of activity of the prefectural resident from the demographic point of view. Those cities having a ratio of over $100 \%$, that is cities where the day population surpasses the night population, were Fukuoka City followed by Kitakyushu City, both having populations of over one million, and Iizuka City. Various other cities also had ratios of over $100 \%$. When the life dependence scale was used, which is the converse of the above index and shows to what degree the residents are dependent on other municipalities, the former community had greatly changed and the range has been greatly extended to form new communities (Egawa et al., 1980a). The results of these two surveys show the quantitative change of the activities of the residents.

Various typological classifications of the regions were attempted based on the survey of "Community for health care" and the commuting areas obtained from the national census (1965-1975). The commuting areas were defined in their respective order, according to the extent that the residents of cities, towns and villages commuted to other areas. The criteria for typology was the first and third order of the commuting areas and places where more than $5 \%$ of the residents commuted. This was in accordance with the fact that there are many depressed areas in Fukuoka Prefecture due to the decline of industries. The survey of commuting areas is not a quantitative analysis as mentioned before, but a way to show the relationship between the cities, towns and villages. When the $5 \%$ point was selected, Fukuoka Prefecture could be divided into two large regions centering around Kitakyushu City and Fukuoka City. Inside these two major regions, there are several small nuclei. When the region for health care is considered, the question remains whether to consider the small nuclei as independent regions or as belonging to the two major regions. Both the independent survey and the national census of 1980 show similar typology.

If the primary commuting areas are considered, the Chikuho Area, Iizuka City, Nogata City and Tagawa City areas respectively, must be included under small centers and commuting areas. Especially in the case of Tagawa City, although there is a flow to Kitakyushu City, in actuality, from the transportation conditions and demographic characteristics, it could be considered largely as an independent region. Iizuka City and Nogata City have also similar independent living areas which is a characteristic of Chikuho Area, although the former has some relationship with Fukuoka City and the latter with Kitakyushu City. However, in the case of Yamada City, although it is a large administrative district, it shows only a relationship with Iizuka City. This is due not only to the transportation and road conditions but also to the fact that the young have moved to other areas and only the elderly have remained. In Amagi City and Asakura Area, the residents do not commute to Kurume City which is geographically closer, but to Fukuoka City. In other words, due to the decline of the major industries in the Chikuho Area, which is in central Fukuoka Prefecture, and also due to the transportation conditions, the activity range of the residents has contracted and has been left out in the general expansion of commuting areas. This has led to small commuting areas in which the residents 
commute to the outlying areas where some work, though not much, remains.

From the results of the comprehensive analysis of the day/night population ratio, the degree of dependence of livelihood and the commuting area survey, it is clear that the cities, towns and villages form several living areas. In other words, Fukuoka Prefecture could be divided into the two large living areas of Fukuoka City and Kitakyushu City both having population of over one million. These two large areas have within them local living areas centering on Tagawa City - Yamada City and Kurume City-Omuta City, respectively. These local living areas are dependent on either Fukuoka City or Kitakyushu City (Fig. 1).

From these facts, it is clear that the living area of the residents form communities which are based on the location of the industries (Ohtomo, 1979).

The health care region needed for planning should be based on the daily living area of the residents no matter what level of care is being considered. In the case of Fukuoka Prefecture, the health planning region should be based on the analysis of the living areas which has been made.

If the level of health care necessary within activity areas of the residents is set at the secondary level, from the above results, the health planning regions could be designated as that of Kitakyushu, Fukuoka, Chikuho and Kurume-Omuta. If the health care level is set at the tertiary level, it could be designated as Kitakyushu, Fukuoka and the Chikugo regions (centering around cities, Kurume and Omuta) with the exception of Amagi.

The health planning region is intimately influenced by the living range of the residents, and the regional characteristics deriving from the geographical and industrial location.

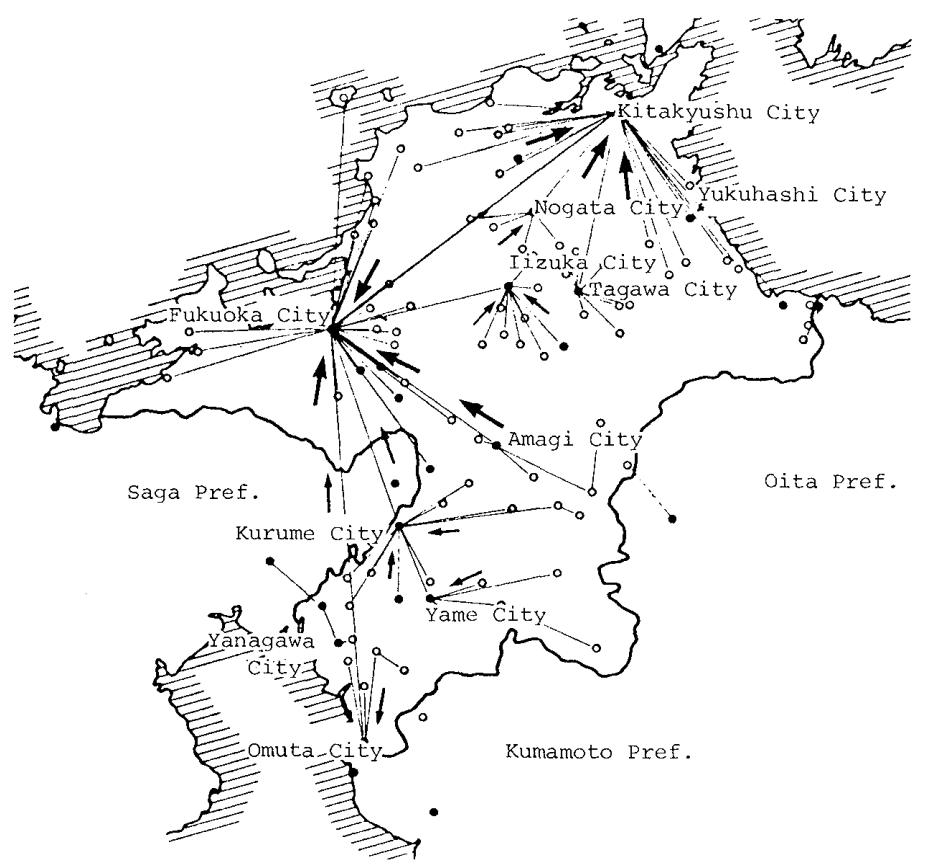

Fig. 1. The commuting area obtained from the 1975 national population census, Vol. 4 was defined as the area to which the most residents commuted. 


\section{Comparison with the Wide Administrative Units}

From the analysis of the demographic change due to industrial innovation which is mainly that of population structure, employment structure, geographical conditions, day/ night population ratio arising from the means of transportation and in addition the population size, location, flow and composition made clear from the analysis of the commuting areas, the stratified activity ranges of the residents could be divided into the four major regions centering around the two metropolitan regions of Fukuoka City and Kitakyushu City and the two local urban centers of Chikuho Region (Iizuka and Nogata and Tagawa cities) and Kurume-Omuta Region (Kurume and Omuta cities). In each case, there regions include several cities, towns and villages (Ando et al., 1979; Muroi, 1979; Egawa et al., 1980b).

Formally, the regional unit for the lives of the residents were the prefectures cities, towns and villages. In the health care field, there are also the administrative units of the Health Centers. However, the activity range of the residents has greatly expanded, and each administrative unit has also been expanded. These are the concepts of the "wide range city, town, village areas" of the Ministry of Local Government, and the "local living areas" of the Ministry of Construction. The former areas can be combined to form the latter. The Public Health Bureau of the Ministry of Health and Welfare has designated model prefectures and has made surveys in order to form health planning regions. As a result, it was decided that the health care planning regions were to be identical to the "wide range city, town, village areas". As is clear from Fig. 2, the living area of the residents of this prefecture is more or less identical to that of the "local living area". If health care is to be considered as a part of the daily life of the people, the

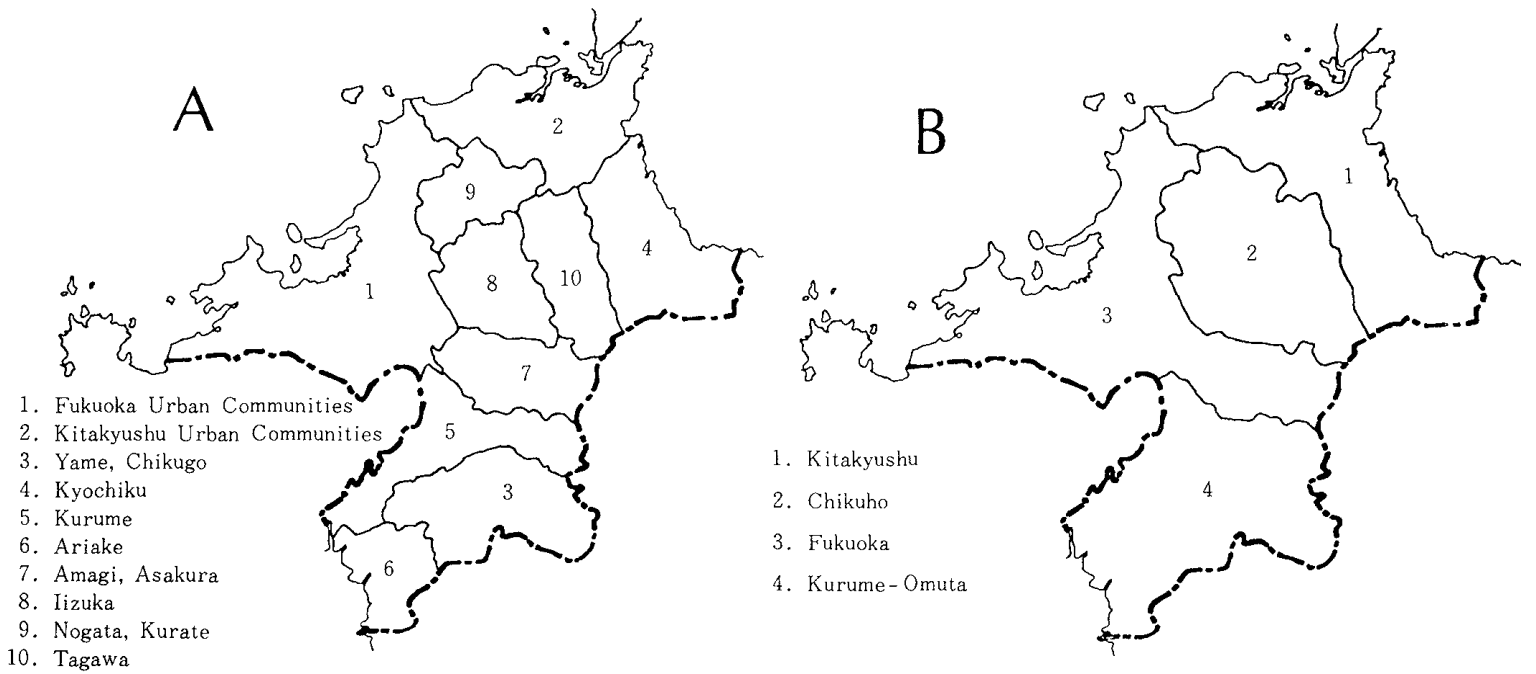

Fig. 2. An example of the wide administrative area in Fukuoka Prefecture.

A : The "wide range city, town, village area" of the Ministry of Local Government.

B : The "local living area" of the Ministry of Construction. 
locations of the industries in the region are important for the livelihood of the residents. If the industrial structure changes, the living conditions are bound to change, and the new industrial structure will lead to a considerable change in the disease composition. Therefore, in health care planning, adequate consideration, of the industrial structure is also necessary. In these circumstances, as mentioned before, from the observation of social change, prefectural health planning should be made in compliance with the expanded and fluid life system of the residents and the expansion of the fixed wide administrative units proposed by the various ministries.

Therefore, designation of the region for health planning should not be made in a fragmented way from the various development plans, economic plans and social plans, but in a coordinated way centering around the residents.

However, the basis of health planning of Fukuoka Prefecture is in all cases, the same as that of the local governments. The First National Comprehensive Development Plan (1962) and the Second National Comprehensive Development Plan (1970), focused only on the new development of industries and as has been pointed out, the lives of residents have not been considered. The Third National Comprehensive Development Plan (1977) with the basic object of "A planned development for a comprehensive environment" has become a national policy. The intention of the Plan is to emphasize that man and nature are in harmony with stable, healthy and cultural living conditions, taking into consideration that the limited national resources and the regional, historical and traditional culture" have been given attention as a national policy. However, in the case of this prefecture, there are no actual plans for regional development.

Health care planning should be first thought of as an area of the residents life activity before realizing these kinds of goal. The living sphere of residents should be analyzed from the social, economical and industrial location point of view. These aspects are central to a regional based planning policy.

\section{Verification of Regional Designation}

It has been confirmed from the analysis of the resident's commuting pattern data and related literature that the health planning regions in Fukuoka Prefecture consist of the four living areas of Kitakyushu, Fukuoka, Chikuho and Kurume-Omuta. From a qualitative methodology it was seen that these four regions are identical with the "local living area". The first quantitative to verify this result was made by using the weighted paingroup method and principal component analysis. The dimensions of urbanization and industrialization which determine the regional social structure of this prefecture was made clear and the 107 cities, towns and villages could be classified into a fixed regional classification (Nito et al., 1981).

From the vantage of the Fuzzy Sets-theory, a multivariate technique centering around clustering analysis was next utilized to analyse the commuting data of this prefecture. A 
living area was confirmed to exist between the life dependency index at the $20 \%$ level of the group area region pattern and the $10 \%$ level of the large region pattern. From the life dependency index level of $12 \%$, it was divided into the two regions centering around Kitakyushu City and Fukuoka City. At the $16 \%$ level, the Chikuho area, in the center of the prefecture, is wedged between the two large regions and more or less completely covers the former mining areas. It has a high degree of socio-economic homogeneity which was ascertained from the results of the homogeneous area analysis. At the 16\% level, the clustering reconfirmed fairly well the results of the qualitative obtained region designation especially in the case of Kitakyushu Region and Fukuoka Region (Fig. 3 ). However, the Kurume-Omuta Region which was thought to form an independent region from the qualitative analysis formed part of the Fukuoka Region.
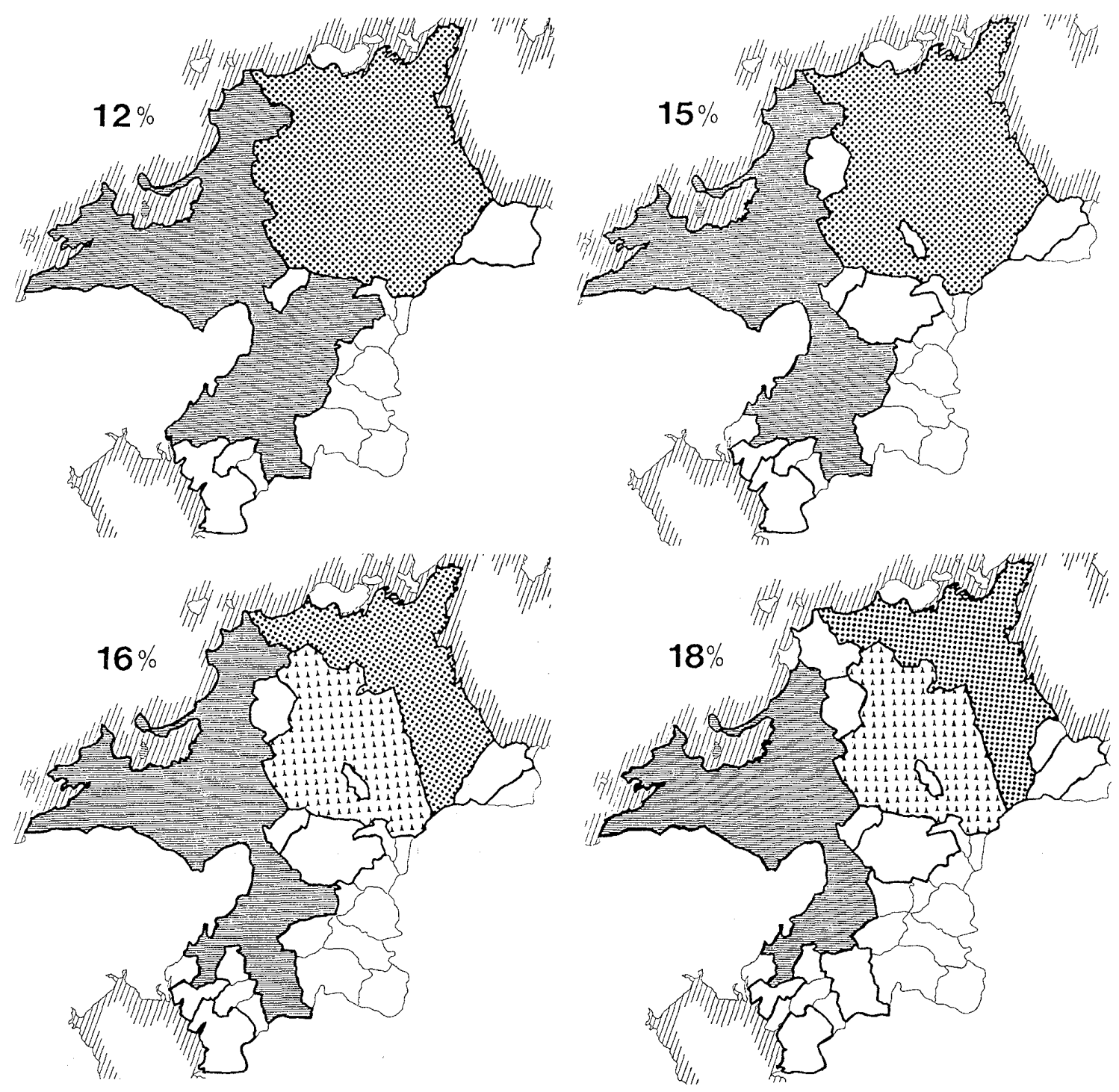

Fig. 3. These maps show the geographical limits resulting from the clustering analysis of the commuting data among the life depending indices at the $12 \%-18 \%$ level, in Fukuoka Prefecture. 
In the Fukuoka Region, which covers the predominantly rural areas in the southern part of the prefecture, it is conjectured that there exists a functionally independent region centering around Kurume-Omuta. If the dendrogram formation of the cluster analysis is further explored, it is clear that the surrounding area has Kurume City as the functional center. Also, Chuo-ku and Hakata-ku in the Fukuoka Region, being the center of both cities, Kurume and Omuta, had a high 24\% level of dependency. Clustering was again made after the flow of the commuting pattern was interrupted, at the same $16 \%$ level. Kurume City merged with the surrounding cities, towns and village to form an independent living area.

The commuting population ratio was further obtained from the 107 basic units of the four regions. From the four variables, when relationship between the separability of each region and the possibility of an error in classification was analyzed, the separability of Fukuoka Region and Kurume-Omuta Region was high and error possibility was practically non-existent. Therefore, the results were identical with the results obtained from the qualitative analysis (Nito et al., 1982). Thus, the health care planning regions of Fukuoka Prefecture were identical whether using the qualitative approach or the quantitative approach from the analysis of the living area of the residents.

\section{References}

Ando, K., Nakata, M. \& Makino, Y. (1979) : Chiiki no Shakaigaku - Tokai-chiho no Shakaigaku-teki Kenkyu-. Zeimu Keiri Kyokai, Tokyo. pp. 141-170. (in Japanese)

Egawa, H., Osada, H., Yusu, K. et al. (1982): Industry and health services - The situation of medical facilities (2)-. Hosp. Adm., 19(4): 57-66. (in Japanese)

Egawa, H., Yusu, K. \& Funatani, F. (1980a): Industry and health services - Historical change of industry and regional characteristics-. Hosp. Adm., 17(1): 71-80. (in Japanese)

Egawa, H., Yusu, K. \& Funatani, F. (1980b) : Industry and health services - Area-setting for health services-. Hosp. Adm., 17(2): 71-77. (in Japanese)

Egawa, H., Yusu, K. \& Funatani, F. (1981a) : Industry and health services - In company-run hospitals-. Hosp. Adm., 18(2) : 11-22. (in Japanese)

Egawa, H., Yusu, K., Funatani, F. et al. (1981b) : Industry and health services - The situation of medical facilities (1)-. Hosp. Adm., 19(1) : 5-13. (in Japanese)

Kurata, M. (1968): Hospital in the community. Hosp. Adm., 5(2): 7-14. (in Japanese)

Kurata, H. (1969a): Health service boundaries of the community. Hosp. Adm., 6(2): 21-27. (in Japanese)

Kurata, M. (1969b): Health service boundaries of the community - Analysis on Population Census of Japan-. Hosp. Adm., 6(4) : 23-28. (in Japanese)

Kurata, M. (1977) : Fuken tan-i ni mita byouin keikaku. The Journal of Public Health Practice. 41(1): 38-44. (in Japanese)

Kurata, M. (1979) : Geographic spheres determined from the standpoint of medical care. Hosp. Adm., 16(3): 9-14. (in Japanese)

Muroi, T. (1979) : Shoken no Chishiki. Nippon Keizai Shinbun-Sha, Tokyo. (in Japanese)

Nito, T., Egawa, H., Yusu, K. et al. (1981) : Social characteristics of health service areas and community -From the socio-metric viewpoint-. Hosp. Adm., 18(1): 19-27. (in Japanese) 
Nito, T., Egawa, H., Yusu, K. et al. (1982): A function-area analysis for health planning - From the point of view of mathematical sociology-. Hosp. Adm., 19(2): 27-35. (in Japanese)

Otomo, A. (1979) : Geographical Distribution of Urban Population in Japan. 1st ed. Taimeido, Tokyo. pp. 44-50. (in Japanese)

Shomura, K. (1979) : Shakai keikaku no houhou ni tuite. Planning Administration, $3:$ 7. (in Japanese)

Tahara, S. \& Suzuki, T. (1977) : Chiiki Keizai no Seicho to Henbo. Gyosei, Tokyo. pp. 345-349.

\section{福岡県における医療計画のための地域範囲の検討}

江川寬

産業医科大学病院管理学教室

要 旨： 産業立地の変化に伴い，その中で包括医療を推進しようとするためには，対象となる住民 のライフ・サイクルを基盤にその方法論とこれに基づく医療圈の設定が必要である.元来, 医療は都道府県,ないしはその中での保健所区域といった行政のための地域で「健康保持」, 「疾病予防」、「診断・治療ならびにリハビリテーション」の各スペクトル部分において断 片的に，かつ種々なる方法を持って展開されてきている．しかしその前提となるのは現在 の行政のための地域とは別の見地から対象とする医療のための地域社会を設定することで あろう。そこで，産業衰退のはげしい福岡県を例に地域の「社会的・経済的側面」と「人 口特性」を中心にその範域を策定し，さらに生活関連性の観点から，住民の行動空間の広 がりにかかわる通勤・通学圈をとりあげ、それに基づく行動圈域と産業立地から考えられ た地理的範囲を併せ考察し，妥当とする「医療のための地域社会」を設定し，それを検証 すべく計量的枠組の中で第一段階として weighted pair-group method と principal component analysis を用い, ひきつついてファジイ集合論の観点がクラスター分析の単一統 分法を中心とする多変量解析的手法を用い分析を試みた結果，16\%レベルで同一の圈域を 導出することができた．本論文は health care region の設定について定性的分析方法亡 計量的分析方法の妥当性について論述した。

J. UOEH（産業医大誌)， 6(2): 131-139 (1984) 